\title{
OPTIMASI CAIRAN PEMBANGKIT MESIN PENCUCI FILM RADIOGRAF PADA LABORATORIUM FISIKA MEDIK UNNES
}

\author{
Diah Rahayu Ningtias, Susilo, Sutikno \\ Jurusan Fisika Fakultas Matematika dan IImu Pengetahuan Alam \\ Universitas Negeri Semarang \\ Semarang, Indonesia \\ E-mail: smadnasri@yahoo.com
}

\begin{abstract}
Abstrak
Telah berhasil dilakukan optimasi mesin pencuci film otomatis Laboratorium Fisika Medik FMIPA Unnes dengan memvariasikan suhu pada cairan pengembang dan cairan fixer sehingga diketahui gambar hasil film radiograf yang paling bagus dan jelas. Obyek yang digunakan pada penelitian ini adalah stepwedge dengan tujuh undakan (step). Variasi suhu yang diberikan mulai dari $28^{\circ} \mathrm{C}$ sampai dengan $40^{\circ} \mathrm{C}$ dengan interval suhu $2^{\circ} \mathrm{C}$. Pada mulanya dilakukan variasi cairan pengembang dengan suhu fixer yang digunakan adalah $30^{\circ} \mathrm{C}$, kemudian dianalisis dengan mencari nilai kerapatan (densitas) pada masing-masing undakan di film radiograf. Setelah diketahui suhu cairan pengembang paling optimal yang dapat digunakan untuk mencuci film radiograf maka suhu tersebut digunakan pada pemvariasian suhu cairan fixer. Suhu cairan pengembang paling optimal yang dapat digunakan untuk mencuci film radiograf adalah pada $32^{\circ} \mathrm{C}$ dan untuk suhu cairan fixer yaitu pada $32^{\circ} \mathrm{C}$.
\end{abstract}

Kata kunci: Mesin pencuci film otomatis; suhu; cairan pengembang; cairan fixer

\begin{abstract}
Automatic film washing machine (TAEHN, model TM 300 E in Physics Laboratory of FMIPA Unnes was successfully optimized by variating temperatures of developer and fixer solution in the range of $28^{\circ} \mathrm{C}$ until $40^{\circ} \mathrm{C}$ with temperature interval of $2^{\circ} \mathrm{C}$. At the first, developer solution was variated at controlled fixer temperature namely $30^{\circ} \mathrm{C}$, then it was analyzed to fixer determine density of each radiograph film. The optimum temperature of developer solution is available to varying temperature of fixer solution. The optimum temperatures of developer solution and fixer solution are $32^{\circ} \mathrm{C}$ and $32^{\circ} \mathrm{C}$, respectively.
\end{abstract}

Keywords: Automatic film washing machine, temperature, developer solution, fixer solution.

\section{PENDAHULUAN}

Aplikasi teknologi sinar-X telah banyak dimanfaatkan dalam berbagai bidang, salah satunya dalam bidang kesehatan atau medik di bagian radiologi. Salah satu peralatan penunjang medik di instalasi radiologi adalah pesawat Roentgen yang menggunakan radiasi pengion untuk mendiagnosis suatu penyakit dalam bentuk gambaran anatomi tubuh yang digambarkan dalam film radiografi. Sinar- $X$ menghasilkan radiasi yang menimbulkan efek luminisensi pada bahan pembentuk lapisan film setelah sinar-X melewati bahan yang ditembusnya dan menimbulkan efek menghitamkan film setelah dilakukan pemrosesan film di kamar gelap (Suyatno, 2008).
Saat ini telah mulai dikembangkan pencucian radiograf dengan menggunakan mesin otomatis yang memiliki banyak kelebihan, diantaranya menghemat waktu dimana untuk mendapatkan film kering hanya diperlukan waktu 5 menit. Selain itu, dalam pencucian film dengan mesin otomatis ini pengendalian dan proses standarisasi mudah dipertahankan. Untuk mendapatkan mutu gambar yang bagus, perlu dilakukan optimasi mesin pencucinya, dengan begitu akan dihasilkan film radiograf yang memiliki kualitas ketajaman gambar yang optimal (Garret, 2001).

Pengolahan film secara otomatis diharapkan mampu menghasilkan radiograf yang standar dan konsisten. Namun demikian, meskipun telah dilakukan secara 
otomatis tetapi masih memungkinkan hasil pengolahan film tersebut tidak sesuai dengan yang diharapkan. Hal ini dapat terjadi karena kinerja mesin pengolah film otomatis perlu dilakukan uji terhadap hasil kinerja mesin pengolah film otomatis (Raharjo, 2006). Ada 3 faktor yang mempengaruhi pembangkitan pada film radiograf, yaitu: suhu cairan pembangkit, kesegaran cairan atau keadaan cairan pembangkit dan waktu pembangkitan (Septiadi, 2008).

Awal Maret 2012 Laboratorium Fisika Medik FMIPA Unnes mendapatkan peralatan baru berupa satu unit Mobile X-ray (biasa digunakan pada rumah-sakit Daerah atau Puskesmas), dengan merk/type Mednif/SF-100BY dan unit satuan pemrosesan film otomatis Model: TM-300E (Anonymous, 2012).

Permasalahan yang ada dalam hal ini adalah belum dilakukannya pengoptimasian pada mesin pencuci film otomatis yang dimiliki oleh laboratorium fisika medik FMIPA Unnes, sehingga dalam proses pencucian film radiograf hanya mengikuti panel indikator dari pabrik yang memproduksi mesin tersebut. Dengan belum dilakukannya pengoptimasian pada mesin pencuci film otomatis tersebut maka juga belum diketahui faktor apa saja yang perlu dilakukan untuk mendapatkan hasil film radiografi dengan gambar citra mutu terbaik.

Berdasarkan permasalahan yang terdapat dalam penggunaan mesin pencuci film otomatis tersebut maka penelitian ini bertujuan untuk mengoptimasikan mesin pencuci film otomatis yang baru dimiliki oleh laboratorium fisika medik FMIPA Unnes, karena pada dasarnya setiap kali terdapat barang baru maka lebih baik untuk dilakukan pengoptimasian supaya dapat dilakukan secara maksimal dalam pemakaiannya. Pada penelitian ini upaya untuk melakukan optimasi mesin pencuci film otomatis dilakukan dengan pengoptimalan pada suhu cairan pengembangnya yaitu cairan pengembang dan cairan fixer.

\section{METODE}

Penelitian ini memiliki beberapa tahapan yaitu memapar film dengan menggunakan pesawat radiografi konvensional (RK), mencuci film yang telah dipapar menggunakan mesin pencuci otomatis untuk kemudian dianalisis menggunakan densitometer untuk mengetahui nilai kerapatan (densitas) pada masing-masing undakan (step) pada film radiografi. Bahan yang digunakan pada penelitian ini adalah cairan pembangkit yang terbuat dari hydroquinone dan cairan fixer yang berfungsi sebagai penghalus pada film radiografi yang telah dibangkitkan gambarnya. Sementara alat yang digunakan pada penelitian ini adalah satu unit Mobile $X$-ray dengan merk/type Mednif/SF-100BY dan unit automatic processing film dengan Model: TM-300E. Peralatan dan bahan berupa komponen lepas lainnya adalah: kaset x-ray, kaset stand, safety lamp, lightbox, film agfa ukuran $18 \times 24 \mathrm{~cm}$.

Penelitian ini dilakukan dengan memvariasikan suhu pada cairan pengembang dan cairan fixer yang digunakan untuk proses pecucian film radiografi mesin pencuci film otomatis yang ada di Laboratorium Fisika Medik FMIPA Unnes. Film radiografi yang telah dipapar menggunakan pesawat sinar- $X$ dengan stepwedge sebagai obyeknya kemudian dicuci dengan mesin pencuci film otomatis dengan suhu cairan fixer yang digunakan adalah $30^{\circ} \mathrm{C}$ dan suhu cairan pengembang yang divariasikan antara adalah $28^{\circ} \mathrm{C}$ dan $40^{\circ} \mathrm{C}$ dengan interval suhu $2^{\circ} \mathrm{C}$. Setelah didapatkan nilai kerapatan untuk masing undakan pada obyek dan diketahui suhu cairan pengembang paling optimal yang dapat digunakan untuk mencuci film radiografi maka untuk selanjutnya dilakukan pemvariasian pada cairan fixer dengan variasi suhu yang digunakan secara berturut-turut adalah sama seperti pada variasi cairan pengembang.

Untuk analisis data yang dilakukan yaitu dengan mengetahui nilai kerapatan pada masing-masing vaiasi suhu yang telah dilakukan. Alat yang digunakan untuk mengetahui nilai kerapatan adalah dengan menggunakan densitometer. Pada awalnya dilakukan kalibrasi densitometer yang akan digunakan dengan menekan tombol "zero" (warna biru) pada densitometer hingga muncul tulisan "Densitometer zero processing" selanjutnya menekan tuas pengukuran hingga muncul tulisan "density : 0.00 ", setelah itu meletakkan film radiografi yang akan diketahui nilai kerapatannya pada tuas pengukuran. Kemudian menekan tuas pengukuran hingga muncul hasil kerapatan pengukuran pada layar. Untuk setiap step yang ada diambil tiga titik dan kemudian diambil rata-ratanya sehingga hasil yang didapatkan merupakan hasil yang valid. Setelah didapatkan nilai kerapatan untuk 
masing-masing step pada setiap film radiografi yang telah diekspose dengan stepwedge sebagai obyeknya, maka selanjutnya dibuat grafik hubungan antara variasi suhu pada cairan dengan nilai kerapatan yang didapatkan sehingga dapat dilihat suhu yang paling optimal pada cairan pengembang dan cairan fixer yang digunakan untuk mencuci film radiografi.

\section{HASIL DAN PEMBAHASAN}

Setelah proses pencucian film radiografi selesai dilakukan, maka untuk dapat mengetahui nilai kerapatan dari masing-masing film adalah dengan menggunakan densitometer. Pada densitometer akan langsung terlihat besar nilai kerapatan di tiap-tiap undakan obyeknya, sehingga untuk mengukur nilai kerapatan dilakukan dengan mengambil beberapa titik untuk tiap-tiap stepnya dan pada penelitian ini diambil tiga titik untuk tiap-tiap undakan pada obyek yang digunakan. Setelah dihasilkan nilai kerapatan untuk tiap-tiap step pada obyek, maka selanjutnya adalah dihitung nilai rataratanya dan hasil akhir pengukuran kerapatan adalah sebagai berikut :

Tabel 1. Nilai kerapatan pada masingmasing undakan untuk variasi suhu cairan pengembang.

\begin{tabular}{cccccccc}
\hline & $28^{\circ}$ & $30^{\circ}$ & $32^{\circ}$ & $34^{\circ}$ & $36^{\circ}$ & $38^{\circ}$ & $40^{\circ}$ \\
\hline 1 & 0.57 & 0.53 & 0.76 & 0.73 & 0.68 & 0.84 & 0.99 \\
2 & 0.63 & 0.61 & 0.84 & 0.80 & 0.76 & 0.91 & 1.05 \\
3 & 0.69 & 0.68 & 0.93 & 0.86 & 0.84 & 1 & 1.13 \\
4 & 0.84 & 0.90 & 1.13 & 1.03 & 1.03 & 1.20 & 1.3 \\
5 & 1.09 & 1.22 & 1.42 & 1.32 & 1.34 & 1.48 & 1.59 \\
6 & 1.36 & 1.56 & 1.73 & 1.60 & 1.66 & 1.79 & 1.87 \\
7 & 1.87 & 2.11 & 2.23 & 2.09 & 2.19 & 2.29 & 2.36 \\
\hline
\end{tabular}

Dari Tabel 1 tersebut dapat dilihat bahwa nilai kerapatan pada semua suhu yang divariasikan telah berada dalam rentang nilai kerapatan yang dianjurkan untuk film radiografi yaitu mulai dari 0,25 sampai dengan 2,25 sehingga pada suhu pengembang $28^{\circ} \mathrm{C}$ hingga $40^{\circ} \mathrm{C}$ tersebut merupakan suhu yang dianjurkan untuk melakukan proses pencucian film radiografi di mesin pencuci otomatis yang dimiliki Laboratorium Fisika Medik FMIPA Unnes. Namun pada prakteknya masih harus dilakukan pengoptimasian pada mesin tersebut untuk mengatahui suhu yang paling baik digunakan guna pencucian film. Setelah diketahui hasil nilai kerapatan untuk variasi suhu pengembang, maka untuk selanjutya adalah membuat grafik hubungan antara variasi suhu yang digunakan dengan nilai kerapatan yang dihasilkan.

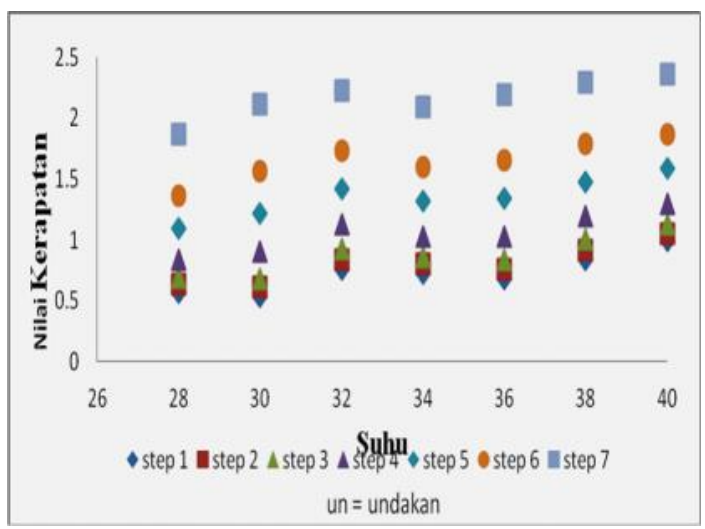

Gambar 1. Grafik hubungan antara suhu cairan pengembang dengan nilai kerapatan

Pada Grafik 1 diinformasikan hubungan antara variasi suhu pengembang dengan nilai kerapatan yang dihasilkan menunjukkan bahwa terdapat nilai kerapatan yang semakin tinggi pada setiap kenaikan variasi suhu yang dilakukan. Pada grafik, terdapat titik dimana hal tersebut menunjukkan nilai kerapatan yang paling optimal atau tinggi yaitu pada suhu $32^{\circ} \mathrm{C}$. Hal tersebut terjadi karena pada suhu $32^{\circ} \mathrm{C}$ merupakan suhu yang mendekati dengan suhu ruangan yaitu $28^{\circ} \mathrm{C}$ dan suhu tersebut menunjukkan bahwa mesin pencuci film telah siap dan mampu melakukan proses pencucian film radiografi dengan baik. Pada kenaikan suhu dari mulai $28^{\circ} \mathrm{C}$ hingga $32^{\circ} \mathrm{C}$ merupakan kenaikan yang wajar terjadi pada setiap mesin yang masih dalam kondisi awal, hal tersebut terlihat bahwa grafiknya terus naik dan berada di titik puncak ketika suhu menunjukkan $32^{\circ} \mathrm{C}$. Hal tersebut dikarenakan pada suhu $32^{\circ} \mathrm{C}$ terlihat citra radiografi yang ditunjukkan pada film telah menunjukkan gradasi yang baik yaitu perbedaan warna dari putih terang hingga hitam pekat yang sempurna dan perbedaan warna dari tiap-tiap step yang dihasilkan tersebut merupakan hasil yang baik untuk pembacaan pada film radiografi. Dan setelah itu nilai kerapatan mulai menurun dimulai dari suhu $34^{\circ} \mathrm{C}$ namun terlihat terjadi kenaikan pada suhu mulai dari $36^{\circ} \mathrm{C}$ hingga $40^{\circ} \mathrm{C}$. Terjadinya penurunan suhu yang dimulai dari $34^{\circ} \mathrm{C}$ merupakan titik kritis dimana hal tersebut dapat terjadi karena beberapa faktor baik dari mulai dilakukan proses pengeksposan hingga proses pencucian film radiografi pada mesin 
pencuci otomatis. Apabila dilihat dari penurunan nilai kerapatan yang tidak terlalu signifikan maka dapat diambil hasil bahwa pada suhu $34^{\circ} \mathrm{C}$ tersebut bukan merupakan suhu optimal untuk proses pencucian film radiografi karena dihasilkan citra radiografi yang tidak terlalu jelas apabila dibandingkan pada suhu antara $28^{\circ} \mathrm{C}$ hingga $32^{\circ} \mathrm{C}$. Faktor penyebabnya adalah ketika pencucian film radiografi pada suhu cairan pengembang $34^{\circ} \mathrm{C}$ tersebut tidak merupakan yang baik untuk proses pencucian dikarenakan pada suhu tersebut menyebabkan cairan pengembang terlalu banyak melakukan pembangkitan pada film ketika proses pencucian sehingga hasil yang didapatkan pada film radiografi adalah terlalu terang yang menyebabkan nilai kerapatannya menurun atau kecil serta muncul kabut dimana hal tersebut menyebabkan citra yang dihasilkan tampak kabur dan tidak fokus atau cerah. Sementara kenaikan nilai kerapatan kembali terjadi pada suhu cairan pengembang mulai dari $36^{\circ} \mathrm{C}$ hingga $40^{\circ} \mathrm{C}$, dimana pada suhu tersebut cairan pengembang yang ada pada mesin pencuci otomatis cukup baik untuk melakukan pencucian. Hal ini ditunjukkan melalui grafik hubungan antara suhu pengembang dengan nilai kerapatan yang semakin naik. Memang pada suhu ini citra yang dihasilkan menunjukkan hasil yang baik dengan ditandai tidak terdapat kabut pada film radiografi yang dapat mengganggu dalam penglihatan. Dari analisis dan pembahasan yang telah dilakukan untuk variasi suhu cairan pengembang maka didapatkan suhu yang paling optimal pada cairan pengembang guna pencucian film adalah $32^{\circ} \mathrm{C}$ dimana pada suhu tersebut citra yang dihasilkan menunjukkan tingkat kualitas yang tinggi karena terlihat jelas dan tidak terdapat kabut pada film radiografinya.

Setelah diketahui suhu yang optimal untuk cairan pengembang pada mesin pencuci film otomatis di Laboratorium Fisika Medik FMIPA Unnes, maka selanjutnya adalah melakukan pengoptimasian dengan variasi cairan fixer dimana suhu cairan pengembang yang digunakan adalah $32^{\circ} \mathrm{C}$. Langkah untuk mencuci film radiografi pada variasi suhu fixer adalah sama seperti ketika melakukan pencucian pada variasi suhu pengembang. Bagitu pula dengan analisis yang dilakukan, sama seperti pada variasi suhu pengembang yaitu dengan mngukur nilai kerapatan film radiografi menggunakan densitometer. Pengukuran nilai kerapatan ini diambil tiga titik untuk setiap stepnya supaya mendapatkan hasil yang valid dan kemudian dilakukan penghitungan nilai rata-ratanya sehingga didapatkan nilai kerapatan yang berbeda-beda untuk tiap-tiap stepnya pada setiap kenaikan variasi suhu fixer yang digunakan. Dan hasil penghitungan nilai kerapatan dengan menggunakan densitometer yang digunakan adalah sebagai berikut :

Tabel 2. Nilai kerapatan pada masingmasing undakan untuk variasi suhu cairan fixer.

\begin{tabular}{cccccccc}
\hline & 28 & 30 & 32 & 34 & 36 & 38 & 40 \\
\hline 1 & 0.57 & 0.55 & 0.68 & 0.68 & 0.69 & 0.81 & 0.74 \\
2 & 0.64 & 0.72 & 0.82 & 0.77 & 0.75 & 0.83 & 0.83 \\
3 & 0.72 & 0.85 & 0.94 & 0.86 & 0.81 & 0.88 & 0.92 \\
4 & 0.89 & 1.03 & 1.19 & 1.07 & 0.93 & 0.95 & 1.09 \\
5 & 1.13 & 1.29 & 1.47 & 1.37 & 1.11 & 1.04 & 1.34 \\
6 & 1.40 & 1.57 & 1.75 & 1.67 & 1.28 & 1.17 & 1.63 \\
7 & 1.85 & 2.05 & 2.17 & 2.16 & 1.62 & 1.43 & 2.13 \\
\hline
\end{tabular}

Dari Tabel 2 dapat dilihat bahwa nilai kerapatan yang diperoleh untuk masingmasing step pada tiap variasi suhu cairan fixer adalah berbeda dengan nilai hasil kerapatan pada variasi suhu cairan pengembang. Dimana pada variasi suhu cairan fixer nilai kerapatan yang didapatkan adalah lebih kecil dibandingkan dengan nilai kerapatan pada variasi suhu cairan pengembang. Hal ini disebabkan karena cairan fixer merupakan cairan yang bersifat asam dengan nilai $\mathrm{pH}$ antara 3 sampai dengan 4, sementara cairan pengembang merupakan cairan yang memiliki nilai $\mathrm{pH}$ jauh lebih besar karena termasuk kedalam cairan yang bersifat basa dengan nilai $\mathrm{pH}$ antara 10 sampai dengan 11,5. Pada nilai kerapatan untuk variasi suhu cairan fixer ini pun masih dalam rentang nilai kerapatan yang dianjurkan untuk film radiografi dimana antara rentang 0,25 hingga 2,50. Dengan demikian dapat diketahui bahwa untuk variasi cairan fixer yang dilakukan yaitu antara suhu $28^{\circ} \mathrm{C}$ sampai dengan suhu $40^{\circ} \mathrm{C}$ masih dalam batas suhu yang dianjurkan untuk proses pencucian film radiografi. Untuk analisis kerapatan dengan menggunakan densitometer pada variasi suhu cairan fixer dapat dilihat melalui grafik yang telah dibuat, yaitu sebagai berikut : 


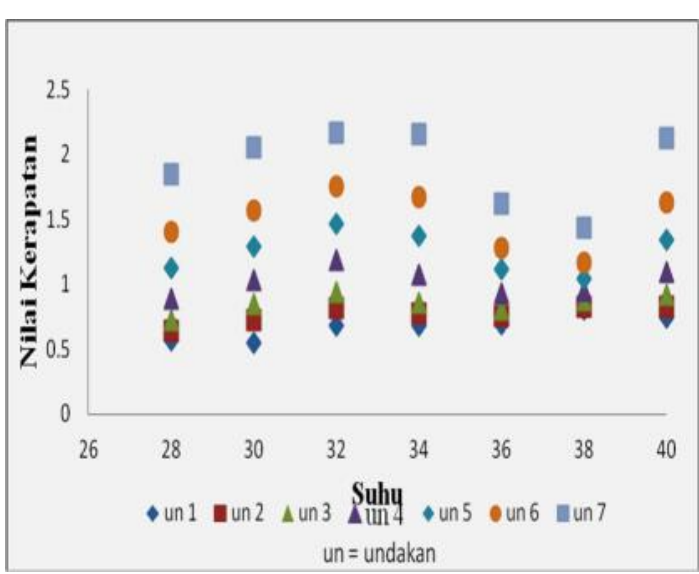

Gambar 2. Grafik hubungan antara suhu cairan fixer dengan nilai kerapatan.

Apabila dilihat dari grafik pada Gambar 2 yang telah dibuat, maka dapat diketahui nilai kerapatan pada film radiografi yang paling tinggi dan yang paling rendah untuk setiap variasi suhu yang digunakan. Didapatkan nilai hasil film radiografi yang paling bagus yaitu terlihat jelas dan tidak terdapat fog atau kabut dalam filmnya yaitu pada suhu cairan fixer $32^{\circ} \mathrm{C}$. Hal tersebut juga dapat dilihat melalui grafik hubungan antara suhu cairan fixer dengan nilai kerapatan yang telah dibuat yaitu tampak bahwa pada suhu cairan fixer $32^{\circ} \mathrm{C}$ menunjukkan nilai tertinggi, sementara nilai terendah terdapat pada suhu cairan fixer $38^{\circ} \mathrm{C}$. Nilai kerapatan tertinggi pada suhu $32^{\circ} \mathrm{C}$ dapat terjadi dikarenakan pada suhu tersebut cairan fixer telah dalam keadaan suhu yang sempurna dimana mendekati suhu kamar normal yaitu $28^{\circ} \mathrm{C}$ sehingga pemanasan yang dilakukan pada mesin pencuci otomatis juga telah pas dan sempurna pula dan pada akhirnya dihasilkan film radiografi yang paling bagus. Sementara hasil film radiografi yang paling rendah kualitasnya adalah terletak pada variasi suhu fixer $38^{\circ} \mathrm{C}$ karena citra radiografi yang dihasilkan tampak buram, tidak jelas dan terdapat banyak fog atau kabut. Hal tersebut dikarenakan pada suhu $38^{\circ} \mathrm{C}$ tidak terjadi pemanasan yang sempurna dimana suhu yang digunakan terlalu tinggi untuk proses pencucian film radiografi sehingga menghasilkan nilai kerapatan yang rendah. Tampak pada grafik bahwa terjadi penurunan yang sangat signifikan pada suhu tersebut, dimana nilai kerapatan pada suhu cairan fixer sebelumnya yaitu mulai dari $34^{\circ} \mathrm{C}$ terus menurun hingga pada suhu $38^{\circ}$. Ketika pada penurunan ini dapat disebut juga sebagai titik kritis dimana suhu yang memiliki nilai kerapatan sangat rendah.
Faktor lain yang menyebabkan penurunan nilai kerapatan yang sangat signifikan tersebut adalah kondisi suhu cairan fixer yang terlalu tinggi, namun apabila dikatakan seperti itu ketika pada suhu cairan fixer $40^{\circ} \mathrm{C}$ terjadi kenaikan nilai kerapatan lagi secara signifikan. Jadi kenaikan suhu cairan fixer yang tinggi tidak dapat dikatakan untuk menyebutkan bahwa apabila suhu cairan fixer yang digunakan terlalu tinggi akan mengakibatkan nilai kerapatan yang sangat rendah. Untuk itu faktor nilai $\mathrm{pH}$ lah yang menyebabkan terjadinya penurunan nilai kerapatan secara signifikan dan begitu pula dengan kenaikan nilai kerapatan secara signifikan yang terjadi juga dapat dikatakan sebagai akibat dari $\mathrm{pH}$ yang bersifat asam pada cairan fixer tersebut. Jadi, telah diketahui suhu yang paling optimal untuk cairan fixer yang digunakan pada mesin pencuci otomatis di Laboratorium Fisika Medik FMIPA Unnes adalah terletak pada suhu $32^{\circ} \mathrm{C}$.

\section{SIMPULAN}

Telah dilakukan optimasi mesin pencuci film radiografi yang dimiliki oleh laboratorium fisika medik FMIPA Unnes dengan memvariasikan suhu pada cairan pengembang dan cairan fixer sehingga dapat diperoleh hasil film radiografi dengan kualitas yang baik yaitu terlihat jelas tanpa adanya kabut. Semakin tinggi suhu cairan pengembang yang diberikan ketika proses pencucian film radiografi, maka nilai kerapatan masing-masing step pada obyek akan semakin besar. Dengan begitu hasil film radiografi yang ada juga semakin jelas dan memiliki kualitas yang baik, dimana suhu pengembang yang divariasikan yaitu antara $28^{\circ} \mathrm{C}$ hingga $40^{\circ} \mathrm{C}$ dengan interval $2^{\circ} \mathrm{C}$ dalam rentang nilai kerapatan yang dianjurkan untuk pembacaan film radiografi yakni antara 0,57 hingga 2,3 dan rentang kerapatan pada variasi suhu cairan fixer antara 0,54 hingga 2,13. Suhu cairan pengembang yang paling optimal untuk proses pencucian film radiografi adalah $32^{\circ} \mathrm{C}$ dan suhu cairan fixer yang paling optimal untuk proses pencucian film radiografi adalah $32^{\circ} \mathrm{C}$. Diharapkan pada penelitian lanjutan untuk dapat melakukan pengoptimasian mesin radografi dengan variabel lain misalnya saja penggunaan cairan-cairan pembangkit yang lebih ramah lingkungan atau lain sebagainya. 


\section{DAFTAR PUSTAKA}

Anonymous. 2009. The mobile diagnostic $X$ ray machine - The user manual, Type SF100 BY, Shanghai Guang Zheng medical instrument limited company.

Boel \& Trelia. 2009. Dental radiografi prinsip dan teknik. Medan : USU Press.

Garret, W.R. 2001. Radiography in modern industry 4th edition. Rochester, New York : Eastman Kodak Company.

Jujun, S., Anam, C., \& Azam, M. 2008. Pengaruh kenaikan suhu cairan pengembang terhadap kerapatan radiograf. Jurnal Berkala Fisika. Vo 11, NO 3. ISSN : 1410-9662.

Kakooei, H., Ardakani, M.B., \& Sadighi, A. 2007. Determinant of exposure to chemical pollutants in wet $\mathrm{x}$-ray film processing in iran. Pakistan Journal of Biological Science, 10 (14): 2341-2347. ISSN 1028-8880.

Krupinski, et al. 2007. Digital radiograhy image quality: image processing and display. American college of radiology, 4:389-400.

Kasap, S.O and Rowlands J.A. 2002. Directconvertion plat-panel $\mathrm{x}$-ray image detectors. iee procedings circuit devices. Sysx, Vol 149, NO 2.
Oky, R.D., Azam, M \& Umiati, N.A.K. 2006. Uji hasil kinerja mesin pengolah film otomatis mini medical. Jurnal Berkala Fisika. Vol 9, NO 2. ISSN : 1410-9662.

Susilo, Maesadi TN, Kusminarto \& Wahyu SB. 2011. Kajian fisika indekskeabuan dengan teknik radiografi digital pada pemeriksaan tulang metastatik. Jurnal Pendidikan Fisika Indonesia. Vol 8, NO 1. ISSN 16931246.

Susilo, Sutikno \& Sunarno. 2012. Optimasi sistem radiografi sinar-x untuk pengembangan laboratorium fisika medik unnes semarang. Proceeding Seminar Nasional MIPA Unnes Tahun 2012. ISBN 978-602-185532-4.

Suyatno, F. 2008. Aplikasi radiasi sinar-x dibidang kedokteran untuk menunjang kesehatan masyarakat. Yogyakarta : Balai Press. 